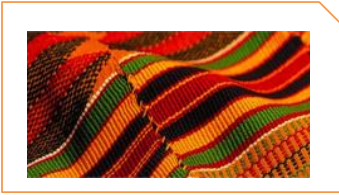

Kente: Cape Coast Journal of Literature and the Arts

Online ISSN: 2579-0285

https://doi.org/10.47963/jla.v2i2.438

Azags Gandaah

\author{
POETRY
}

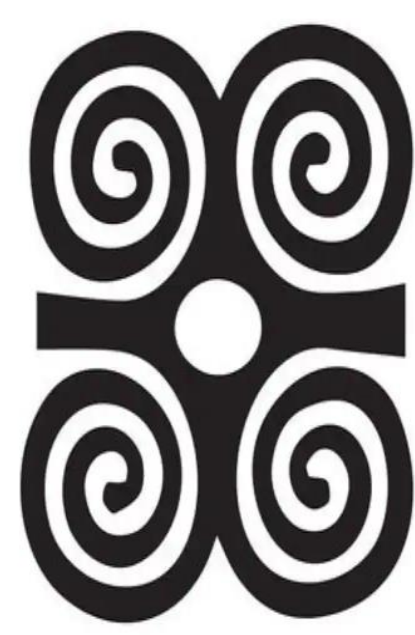


Azags Gandaah

KENTE, 2021

Vol., 2, No. 2

\section{Rwanda (sunset)}

We heard you moan in a hundred

Lamentations

writhing in furnace,

and merely watched with mute mouths

like the world

nodding with pleased hearts.

Yes, we saw you flutter like a broken-wing bird

in the cussed flames stoked by colonialists' white winds,

flamed by our own.

\section{O Rwanda!}

a hundred days of laughter and pain

drowned in a flood of fire and rain

cast your kindred love into a mystery of bloodbath,

turned the schoolchildren's playfields into churchyard

and skull museums.

Ah! a machete raised never touched the earth

but lost in the temple of a boy

whose dying father's pleadings

could not avert his son's bleedings,

and the little girl must make her choice quick

between the gun and phallus,

and mama must witness the scene

before her turn. 
Azags Gandaah

KENTE, 2021

Vol., 2, No. 2

The tormented green hills of Imana mourned

the disappearing thatched huts

and the men with all will of ceasefire,

but for whom it was not their business,

stared you churn and swirl

in a sea of molten flames.

The cathedrals too glowed in red clouds

not of the holy incense in priestly thuribles

but of figures of congregants, who, mistaking

the sacristy for a haven, ran

into the furnace of a nation turned maniac

in heart and mind at once.

And the men in uniform?

They were the masters of the game

Who closed all borders for the sacrifice. 
Azags Gandaah

KENTE, 2021

Vol., 2, No. 2

\section{Rwanda (sunrise)}

We must admit to infirmity of a kind

That engulfed us all,

Not to fate,

And make a public confession

That we were the true murderers of

Our souls,

Sold us to Holocaust.

So busy on the art, we could not listen to the voice

Of conscience,

the ambulance

Was no match for the body count.

Today, we must sit, sober and silent, to question yesterday-

Sober and silent to admit the guilt we all wear:

We were the men we murdered

The massacrers and the massacred

The buried and the buriers

Acting as on the spell of sorcery

Slashing all those familiar faces we knew too well

Laughing cleverly over melting corpses falling on our feet

Burning in a world that no longer knew them.

Today, the sun has burst upon the land again

And the thousand hills of Imana rising all over in green

To a new birth of salaam;

Never more should the sleeping ground moan 
Azags Gandaah

KENTE, 2021

Vol., 2, No. 2

Never more should the dead ashes glow

Never more should the calming dust rise

Never more should the April rains return. 
Azags Gandaah

KENTE, 2021

Vol., 2, No. 2

\section{Crossroads}

Our fathers,

now the river has done us apart

and we, like lepers, unable to wipe off our own sweats,

hold still on to this ancient Baobab roots but with doubts.

When the firmament turns scarlet-red without a rainbow

and the last trumpet bellows, so they say,

where do we turn?

Many have sung on this sweating playground,

motley tones, differing voices of a one-song

each pointing to a true god

the one path with many narrow tracks

but like smokes all snaking to one unknown heaven

some tell tales with promises far sweeter than nectar,

some threatening louder than thunder

The muezzin is calling five

the presbytery stretches her tentacles to global traction

while the ancient grove, o! the forgotten orphan, sat

there a sad lonely naked priest

staring at the few frail feathers-

offer of the day.

We're caught upstream in the middle of a big river

like a lost boatsman finding his way in a whirlpool of seas

where they say all rivers meet, 
Azags Gandaah

KENTE, 2021

Vol., 2, No. 2

tell us, fathers, the path you followed beyond,

have you found the God?

Azags Gandaah (whose real name is Bertrand A. Abelumkemah), is a graduate student at the University of Cape Coast, pursuing MPhil Literature-in-Literature.

Email: $\underline{\text { azags35@gmail.com }}$ 